\title{
The role of hydrogen sulfide in diastolic function restoration during aging
}

\author{
K.O. Drachuk, N.A. Dorofeyeva, V.F. Sagach \\ O.O. Bogomolets Institute of Physiology, National Academy of Sciences of Ukraine, Kyiv; \\ e-mail:8701dk@ukr.net
}

\begin{abstract}
The objective of the study was to examine the effect of exogenous hydrogen sulfide donor, sodium hydrosulfide (NaHS), on the free radical generation, cNOS uncoupling in the myocardium, and diastolic function in old rats. To evaluate diastolic function of the heart, we used pressure-volume (PV) conductance catheter system (Millar Instruments, USA). It was shown that $H_{2} S$ levels in the isolated mitochondria and whole heart homogenates obtained from old age rats were significantly lower comparing with adult animals. The markers of combined oxidative and nitrosative stress (the rate of $\mathrm{O}_{2}{ }^{\circ-},{ }^{\circ} \mathrm{OH}$ generation, pools of $\mathrm{H}_{2} \mathrm{O}_{2}$, diene conjugates, malondialdehyde, uric acid, the activity of $\mathrm{iNOS}$, nitrate reductase, and $\mathrm{NO}_{3}^{-}$pools) were increased in the old hearts in line with cNOS uncoupling. Such changes in NOS coupling resulted in the loss of diastolic relaxation (decrease of the rate of relaxation of the left ventricle ( $d p / d t_{\min }$ ) by 33\%, 3-times increase of the end-diastolic pressure, 1.5-time increase of the time constant of left ventricular relaxation (Tau g) and 2-time increase of the end-diastolic stiffness). It has been found that NaHS inhibits oxidative and nitrosative stress, restores cNOS coupling and constitutive de novo synthesis of nitric oxide (NO), which promotes an improvement of the diastolic function (increase of the dp/dt $\min _{\text {min }}$ by $20 \%$ and decrease of Tau $g$ by $13 \%$ ).

Key words: aging; cNOS uncoupling; heart; hydrogen sulfide; nitrosative stress; oxidative stress.
\end{abstract}

\section{INTRODUCTION}

Progressive reduction in functional reserves of the cardiovascular system in the elderly increases the risk of diseases such as atherosclerosis, hypertension, coronary heart disease, diabetic angiopathy, etc. According to the literature, aged people have abnormal diastolic relaxation which appears before the changes in systolic function of the heart $[1,2]$. At the molecular level, most of functional disorders of the heart tissues and blood vessels are often related to oxidative and nitrosative stress, which results from the overproduction of superoxide radical $\left(\mathrm{O}_{2}{ }^{--}\right)$and generation of excess nitric oxide (NO) [3, 4]. Nowadays, there has been increasing evidence for cNOS uncoupling as the primary source of $\mathrm{O}_{2}{ }^{--}$in the cells $[5,6]$. On the other hand, it was shown that hydrogen sulfide $\left(\mathrm{H}_{2} \mathrm{~S}\right)$ has positive cardiovascular effect through cNOS stimulation $[7,8]$. That stimulation could be a result of cNOS recoupling. Thus $\mathrm{H}_{2} \mathrm{~S}$ can lead to cNOS

(C) K.O. Drachuk, N.A. Dorofeyeva, V.F. Sagach coupling and improve the functional state of the cardiovascular system with aging.

$\mathrm{H}_{2} \mathrm{~S}$, like $\mathrm{NO}$ and $\mathrm{CO}$, belongs to the family of gastransmitters, possesses a powerful cardioand vasoprotective properties, particularly during ischemia-reperfusion injury, atherosclerosis, and hypertension. This effect is due to antioxidant, anti-inflammatory properties of the gas, as well as its ability to regulate the constitutive de novo synthesis of NO [7-10].

The aim of the study was to investigate the effect of $\mathrm{NaHS}$ as exogenous $\mathrm{H}_{2} \mathrm{~S}$ donor on the heart redox status, cNOS coupling and diastolic function in old rats.

\section{METHODS}

The study was conducted on male Wistar rats weighing 280-350 g, which were divided into two groups each of eight animals: adult (6-8 months old) and old (22-24 months old). All experimental procedures were performed in accor- 
dance with the European Communities Council Directive of 24 November 1986 (86/609 / EEC).

Measurement of cardiac function in vivo. The rats were anesthetized using urethane $(1.25 \mathrm{~g} / \mathrm{kg}$, i. p.). The left ventricle (LV) pressure and volume during the cardiac cycle were determined using ultra-miniature pressure transducer catheter $2 \mathrm{~F}$ for rats («Millar Instruments», USA). Catheter was introduced in the LV retrogradely through the carotid artery, which enabled simultaneous recording of pressure and volume signals with their curves visualization during the cardiac cycle [11]. Left ventricular pressure-volume ratio was determined using PVAV 3.6 program («Millar Instruments», USA). LV diastolic function was assessed according to the changes in the rate of relaxation $\left(\mathrm{dP} / \mathrm{dt}_{\min }\right)$, the time constant of active ventricular relaxation (Tau g), end-diastolic pressure (EDP), and end-diastolic stiffness (EDS). We used an exogenous hydrogen sulfide donor, sodium hydrosulfide (NaHS, "Sigma", USA), which was injected intraperitoneally in the concentration of $56.06 \mathrm{mg} / \mathrm{kg}$. This dose allowed us to achieve the plasma NaHS concentration of $10^{-3} \mathrm{~mol} / 1$, which was consistent with that used in research performed on aortic SM [12].

Measurement of endogenous $\mathrm{H}_{2} \mathrm{~S}$ pools and biochemical markers of the oxidative and nitrosative stress and constitutive NO synthesis. In the mitochondria and homogenates of the heart, we determined the markers of oxidative stress such as the rate of superoxide $\left(\mathrm{O}_{2}{ }^{-}\right)$[13], and hydroxyl $\left({ }^{\circ} \mathrm{OH}\right)$ generation [14], pools of hydrogen peroxide $\left(\mathrm{H}_{2} \mathrm{O}_{2}\right)$ [15], eicosanoids thromboxane B2 (TxB2) and leukotriene $\mathrm{C} 4$ (LTC4) [16], arachidonic and uric acids, as well as the markers of lipid peroxidation (LPO), namely diene conjugates (DC) [17] and malonic dialdehyde (MDA) [18] We also determined nitrosative stress- and constitutive NO synthesis markers and such as inducible-NO synthase(iNOS) $[19,20]$ and constitutive NO-synthase (cNOS) activity, pools of nitrate anion $\left(\mathrm{NO}_{3}{ }^{-}\right)$ (marker of peroxynitrite production) [21, 22] and pools of nitrite anion $\left(\mathrm{NO}_{2}^{-}\right)$[22]. $\mathrm{H} 2 \mathrm{~S}$ pools were determined by method [23].

For determine iNOS and cNOS activity, we calculated total activity of NO-synthase using a combination of a classic method [19] and its modification [20], adapted to spectrophotometric measurement of the reaction product - Lcitrulline. For incubation of aliquot samples, we used a substrate mixture $(1 \mathrm{ml})$ of the following composition ( $\mathrm{mmol} / \mathrm{ml}$ ): $\mathrm{KH}_{2} \mathrm{PO}_{4}$ (analytically pure) - 50, $\mathrm{MgCl}_{2}$ (analytically pure) - $1, \mathrm{CaCl}_{2}$ (analytically pure) - 2, NADPH ("Sigma", USA) -1, L-arginine (analytically pure) -2, $\mathrm{pH} 7.0$ for $60 \mathrm{~min}$ at $37^{\circ} \mathrm{C}$. The reaction was stopped by adding $0.3 \mathrm{ml} 2 \mathrm{~N} \mathrm{HClO}_{4}$ (analytically pure). After determining the total activity of NOsynthase, we determined the activity of inducible NO-synthase using the method similar to the previous one with some differences: in the incubation mixture, we added 2 mmol EDTA instead of $\mathrm{CaCl}_{2}$. Then we calculated the activity of cNOS (eNOS + nNOS), subtracting the activity of iNOS from the total NOS activity. The level of nitrosative stress was based on excessive de novo NO synthesis through calciumindependent activity of inducible NO-synthase (iNOS), salvage synthesis of NO through the activity of nitrate reductase.

The measurement of cNOS coupling index. An activity of cNOS-dependent way of $\mathrm{O}_{2}{ }^{--}$ formation was assessed from the changes in the index of cNOS coupling, and it was calculated as cNOS activity related to the rate of $\mathrm{O}_{2}{ }^{--}$ generation $[5,12,16]$.

Mitochondrial fraction was obtained from the rat heart by the method of differential centrifugation [24]. The protein content in mitochondrial suspensions was determined by the Lowry method [25].

In addition to steady-state pools, we determined NaHS -induced changes in these indices in in vivo experiments on old rats. NaHS was injected intraperitoneally in the concentration of $56.06 \mathrm{mg} / \mathrm{kg}$ (30 $\mathrm{min}$ before decapitation). The 
results are presented as percentage relative to the values of adult animals that are taken for $100 \%$.

Data are expressed as means \pm SE. Results were processed by methods of variation statistics using programs Excel (MS Office XP) and Origin 8.5 (Microcall Inc., USA). Differences between the groups were assessed by ANOVA and T-test. The value of $\mathrm{P}<0.05$ was considered statistically significant.

\section{RESULTS AND DISCUSSION}

Left ventricular diastolic function was assessed by analysis of PV-loops obtained from the catheter inserted in the hearts of old and adult rats. We have shown a significant decrease of the rate of relaxation, $\mathrm{dp} / \mathrm{dt}_{\min }(-5.466 \mathrm{~mm} \mathrm{Hg}$ / $\mathrm{sec} \pm 391 \mathrm{~mm} \mathrm{Hg} / \mathrm{sec}$ in old hearts compared to $-8.131 \mathrm{~mm} \mathrm{Hg} / \mathrm{sec} \pm 308 \mathrm{~mm} \mathrm{Hg} / \mathrm{sec}$ in the adult group). The time constant of LV relaxation, Tau $g$ in old rats was 1.5 times higher than in the control group $(15.8 \pm 0.49 \mathrm{~ms}$ in old rats versus $11.0 \pm 0.2 \mathrm{~ms}$ in adult rats). In addition, in the old rats, end-diastolic pressure, EDP was three times higher than in adult rats $(10.6 \pm 0.7 \mathrm{~mm}$ $\mathrm{Hg}$ compared to $3.45 \pm 0.37 \mathrm{~mm} \mathrm{Hg}$ ). We also found that end-diastolic stiffness, EDS in old rats was 2 times higher than in control group $(0.23 \pm 0.05 \mathrm{~mm} \mathrm{Hg} / \mu \mathrm{L}$ and $0.108 \pm 0.03 \mathrm{~mm}$ $\mathrm{Hg} / \mu \mathrm{L}$, respectively.

Thus, reduction in the rate of LV relaxation together with an increase of the time constant of left ventricular relaxation, end-diastolic pressure and end-diastolic stiffness reflect LV diastolic dysfunction and abnormal heart relaxation in old rats. Diastolic relaxation is often related to the disrupted energy-dependent $\mathrm{Ca}^{2+}$ transport to the sarcoplasmic reticulum and extracellular environment [26]. Reduction of ATP synthesis could be a sequence to the age-associated mitochondrial dysfunction, which develops through oxidative stress [27].

We have found that the injection of NaHS improves ventricular relaxation in old rats. For example, $\mathrm{dP} / \mathrm{dt}_{\text {min }}$ significantly increased by $20 \%(\mathrm{P}<0.05)$, and the Tau $\mathrm{g}$ decreased by $13 \%(\mathrm{P}<0.05)$ (Fig. 1). To establish the possible mechanisms of NaHS-induced effects on cardiohemodynamics in old rats, a series of biochemical experiments was conducted.

As shown in Table 1 and Fig. 2, the rates of $\mathrm{O}_{2} \bullet^{-}$generation in the mitochondria and homogenate of the heart from old rats exceed the control values 3.9 and 3.7 times, respectively. Dismutation of unstable $\mathrm{O}_{2} \bullet^{-}$to stable hydrogen peroxide $\left(\mathrm{H}_{2} \mathrm{O}_{2}\right)$ was 2.1 and 1.4 times greater, compared to the control values. Hydrogen peroxide in turn may be partially reduced to highly reactive hydroxyl radical $\left({ }^{\circ} \mathrm{OH}\right)$ via Fenton reaction. In our experiments, the level of ${ }^{\circ} \mathrm{OH}$ was elevated in the mitochondria and homogenate of the heart from old rats 2.7 and 4.1 times, respectively, which could result from the violation of alternative, non-toxic peroxide metabolism. The

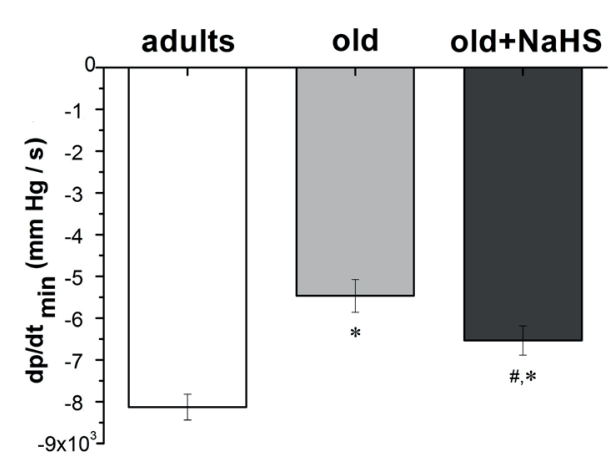

a

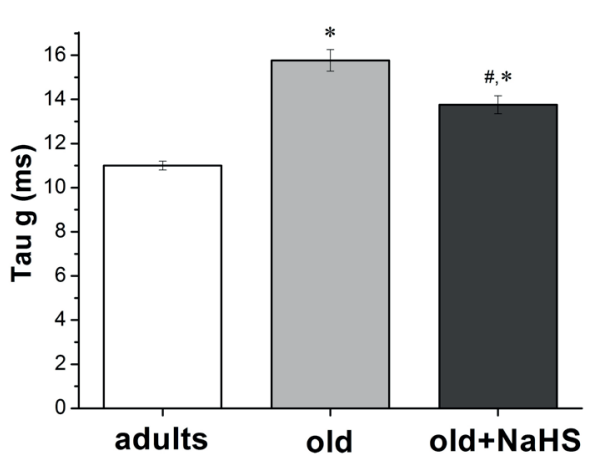

b

Fig. 1. The effect of NaHS on the rate of left ventricular (LV) relaxation ( $\left.\mathrm{dP}^{-} \mathrm{dt}_{\mathrm{min}}\right)$ (a) and the time constant of LV relaxation (Tau g) (b) in old rats. * $\mathrm{P}<0.05$ relative to adult animals; \# $\mathrm{P}<0.05$ relative to old animals, which were not treated with NaHS 
latter involves catalase activity which decreases with aging [28]. It is known that ${ }^{\circ} \mathrm{OH}$ can initiate LPO, primary and secondary products of which are DC and MDA, respectively. It has been revealed that DC levels in the mitochondria and homogenate of the heart from old rats were 9.2 and 8.4 times over the control values, and MDA pools increased 2.7 and 7.3 times, testifying to high intensity of LPO in old animals. Apart from the rate of generation and content of oxygen free radicals, and LPO intensity, we also examined an intensity of some basic ways of $\mathrm{O}_{2} \bullet$-production (oxidative stress trigger). It is known that degradation products of purine nucleotides, xanthine and hypoxanthine, are oxidized to $\mathrm{O}_{2} \bullet^{\bullet-}$ and uric acid by xanthine oxidase [29, 30]. Since xan- thine oxidase is a superoxide-producing enzyme which activity increases in hypoxia, it may serve as a marker of xanthine oxidase way of $\mathrm{O}_{2} \bullet^{-}$production, and, simultaneously, a marker of hypoxia and intensity of ATP degradation. According to the results obtained, the levels of uric acid in old animals exceed the control values 11.9 and 2.6 times. It is also known that free radicals, formed by xanthine oxidase and NADPH oxidase, activate phospholipase A2 by increasing the concentration of intracellular $\mathrm{Ca}^{2+}$, which ensures the release of arachidonic acid from phospholipids of the cell membrane [31-33].In the heart homogenates from old rats, pools of free arachidonic acid increased 2.2 times. Free arachidonic acidis converted to TxB2

Table 1. The absolute values of oxidative stress markers in the mitochondria (MCH) and homogenate of the heart from adults, old and old after $\mathrm{NaHS}$ administration $\operatorname{rats}(\mathrm{M} \pm \mathrm{m}, \mathrm{n}=5)$

\begin{tabular}{|c|c|c|c|c|}
\hline & & Adults & Old & Old + NaHS \\
\hline \multirow{2}{*}{$\begin{array}{l}\mathrm{O}_{2} \cdot \text { generation rate, } \\
\text { standart units }\end{array}$} & $\mathrm{MCH}$ & $4.46 \pm 0.41$ & $17.54 \pm 4.44 *$ & $2.6 \pm 0.34^{\#}$ \\
\hline & Homogenate & $3.49 \pm 0.59$ & $12.98 \pm 2.02 *$ & $1.73 \pm 0.23^{\#, *}$ \\
\hline \multirow{2}{*}{$\begin{array}{l}\mathrm{H}_{2} \mathrm{O}_{2} \text { - contents, pmol/ mg } \\
\text { protein }\end{array}$} & $\mathrm{MCH}$ & $12.2 \pm 1.6$ & $25.71 \pm 3.41 *$ & $6.26 \pm 0.51^{\#, *}$ \\
\hline & Homogenate & $2.79 \pm 0.35$ & $3.96 \pm 0.36$ & $1.15 \pm 0.19^{\#, *}$ \\
\hline \multirow{2}{*}{$\begin{array}{l}\cdot \mathrm{OH} \text { generation rate, } \\
\text { standart units }\end{array}$} & $\mathrm{MCH}$ & $4.2 \pm 0.35$ & $11.34 \pm 1.97^{*}$ & $6.57 \pm 0.85^{\#}$ \\
\hline & Homogenate & $0.87 \pm 0.09$ & $3.54 \pm 0.52 *$ & $0.83 \pm 0.04^{\#}$ \\
\hline \multirow{2}{*}{$\begin{array}{l}\text { Diene conjugates, } \mathrm{ng} / \mathrm{mg} \\
\text { protein }\end{array}$} & $\mathrm{MCH}$ & $3.6 \pm 0.23$ & $32.98 \pm 2.5^{*}$ & $7.18 \pm 1.29^{\#, *}$ \\
\hline & Homogenate & $3.4 \pm 0.47$ & $28.52 \pm 2.28 *$ & $6.82 \pm 0.71^{\#, *}$ \\
\hline \multirow{2}{*}{$\begin{array}{l}\text { Malonic dialdehyde, } \mathrm{nmol} / \mathrm{mg} \\
\text { protein }\end{array}$} & $\mathrm{MCH}$ & $2.06 \pm 0.38$ & $5.61 \pm 0.48 *$ & $1.3 \pm 0.16^{\#}$ \\
\hline & Homogenate & $3.75 \pm 0.43$ & $27.23 \pm 1.86^{*}$ & $7.4 \pm 1.01^{\#, *}$ \\
\hline \multirow{2}{*}{$\begin{array}{l}\text { Arachidonic acid, pmol/ mg } \\
\text { protein }\end{array}$} & $\mathrm{MCH}$ & $20.6 \pm 3.8$ & $7.03 \pm 1.15^{*}$ & $21.9 \pm 2.49^{\#}$ \\
\hline & Homogenate & $5.43 \pm 0.58$ & $11.85 \pm 1.55^{*}$ & $1.62 \pm 0.09^{\#, *}$ \\
\hline \multirow{2}{*}{$\begin{array}{l}\text { Thromboxane } \mathrm{B} 2, \mathrm{pmol} / \mathrm{mg} \\
\text { protein }\end{array}$} & $\mathrm{MCH}$ & $2.37 \pm 0.16$ & $2.62 \pm 0.33$ & $0.41 \pm 0.02^{\#, *}$ \\
\hline & Homogenate & $2.25 \pm 0.2$ & $2.4 \pm 0.46$ & $0.6 \pm 0.02^{\#}$ \\
\hline \multirow{2}{*}{$\begin{array}{l}\text { Leukotriene } \mathrm{C} 4, \mathrm{pmol} / \mathrm{mg} \\
\text { protein }\end{array}$} & $\mathrm{MCH}$ & $1.26 \pm 0.12$ & $1.35 \pm 0.15$ & $0.3 \pm 0.05^{\#, *}$ \\
\hline & Homogenate & $0.9 \pm 0.02$ & $0.98 \pm 0.16$ & $0.29 \pm 0.02^{\#}$ \\
\hline \multirow{2}{*}{ Uric acid, nmol/mg protein } & $\mathrm{MCH}$ & $1.19 \pm 0.26$ & $14.18 \pm 1.27^{*}$ & $4.05 \pm 0.47^{\#, *}$ \\
\hline & Homogenate & $1.98 \pm 0.38$ & $5.12 \pm 0.5^{*}$ & $1.57 \pm 0.27^{\#}$ \\
\hline
\end{tabular}

$* \mathrm{P}<0.05$ relative to adult animals $(100 \%)$. \# $\mathrm{P}<0.05$ relative to old rats, which were not treated with NaHS. 

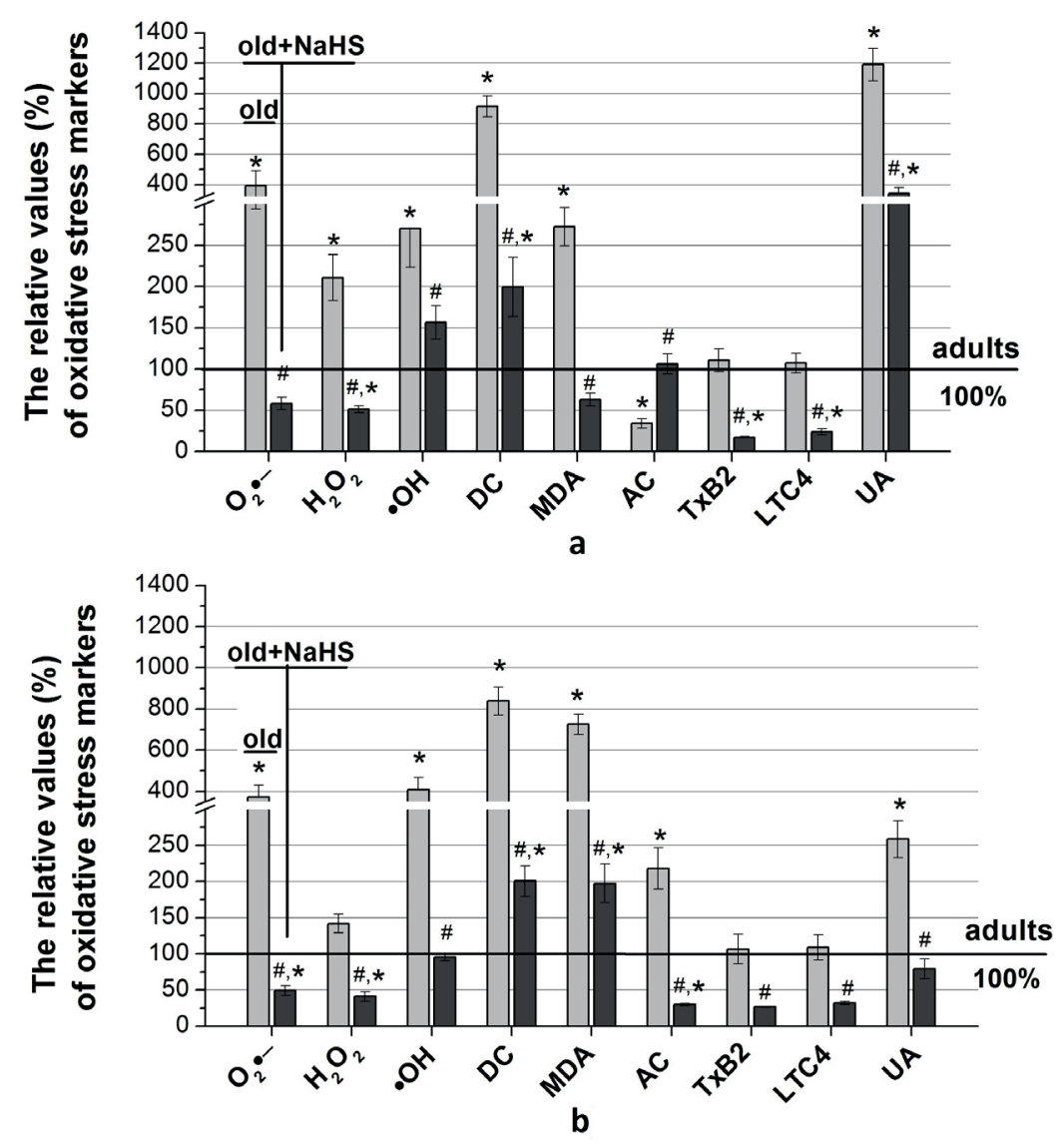

Fig. 2. The relative values of oxidative stress markers in the mitochondria (a) and homogenate (b) of the heart from old rats before and after NaHS injection: $\mathrm{O}_{2} \bullet^{-}$generation rate, the contents of $\mathrm{H}_{2} \mathrm{O}_{2}$, the rate of ${ }^{\bullet} \mathrm{OH}$ generating, the content of diene conjugates (DC), the content of malondialdehyde (MDA), the content of arachidonic acid (AC), the content of thromboxane B2 (TxB2), the content of leukotriene $\mathrm{C} 4$ (LTC4) and uric acid (UA). $* \mathrm{P}<0.05$ relative to adult animals $(100 \%)$. \# $\mathrm{P}<0.05$ relative to old rats, which were not treated with $\mathrm{NaHS}$

and LTC4, by cyclooxygenase and lipoxygenase, respectively, with simultaneous $\mathrm{O}_{2}{ }^{-}$- generation. In our experiments, the levels of TxB2 and LTC4 did not differ from the control values either in the mitochondria or in homogenate of the heart from old animals.

Thus, in the heart tissues of old rats, xanthine- and NADPH- oxidase pathways of $\mathrm{O}_{2}{ }^{-}$ generation are activated, and ROS generation $\left(\mathrm{O}_{2}{ }^{-}, \mathrm{H}_{2} \mathrm{O}_{2},{ }^{\bullet} \mathrm{OH}\right)$ is enhanced, resulting in the development of oxidative stress and LPO.

Table 2 and Fig. 3 show that in old rats, disruption of constitutive de novo NO syntheses develop simultaneously with oxidative stress. Nitric oxide, synthesized by cNOS (eNOS + nNOS) through the oxidation of L-arginine as the substrate, is a powerful cardiovascular regulator. At that, both the gas itself and its oxidized form, $\mathrm{NO}_{2}{ }^{-}$, are involved in the cardiovascular regulation [34]. However, it should be noted that in some cases cNOS may act as a catalyst for $\mathrm{O}_{2}{ }^{-}$generation instead of NO, due to cNOS uncoupling. The latter is observed at lowering of L-arginine bioavailability, in particular, due to enhancing of either arginase activity or a cNOS cofactor, $\mathrm{BH} 4$, as a result of its oxidation by radicals $\mathrm{O}_{2}{ }^{-}$or ONOO-[35]. It has been revealed that in the mitochondria and homogenate of the heart from old animals, cNOS activity decreases 2.1 and 2 times, respectively, relative to controls; $\mathrm{NO}_{2}{ }^{-}$pools as a marker of both constitutive synthesis of $\mathrm{NO}$ and oxygenation 
Table 2. The absolute values of nitrosativestress-, constitutive synthesis of NO markers and $\mathrm{H}_{2} \mathrm{~S}$ levels in the mitochondria $(\mathrm{MCH})$ and homogenate of the heart from adults, old and old after $\mathrm{NaHS}$ administration $\operatorname{rats}(\mathrm{M} \pm \mathbf{m}, \mathrm{n}=5)$

\begin{tabular}{|c|c|c|c|c|}
\hline & & Adults & Old & $\mathrm{Old}+\mathrm{NaHS}$ \\
\hline \multirow{2}{*}{$\begin{array}{l}\mathrm{cNOS}, \\
\mathrm{pmol} / \mathrm{min} / \mathrm{mg} \text { protein }\end{array}$} & $\mathrm{MCH}$ & $3.64 \pm 0.27$ & $1.71 \pm 0.12 *$ & $12.53 \pm 2.81^{\#, *}$ \\
\hline & Homogenate & $6.99 \pm 1.11$ & $3.37 \pm 0.45 *$ & $8.56 \pm 1.32^{\#}$ \\
\hline \multirow{2}{*}{$\begin{array}{l}\text { iNOS, } \\
\mathrm{pmol} / \mathrm{min} / \mathrm{mg} \text { protein }\end{array}$} & $\mathrm{MCH}$ & $1.5 \pm 0.06$ & $3.66 \pm 0.62 *$ & $1.39 \pm 0.25$ \\
\hline & Homogenate & $1.78 \pm 0.26$ & $15.88 \pm 1.18^{*}$ & $3.84 \pm 0.68^{\#, *}$ \\
\hline \multirow{2}{*}{$\begin{array}{l}\text { Nitrate- nitrite reductase, } \\
\mathrm{pmol} / \mathrm{min} / \mathrm{mg} \text { protein }\end{array}$} & $\mathrm{MCH}$ & $0.86 \pm 0.05$ & $2.77 \pm 0.45^{*}$ & $0.51 \pm 0.03^{\#}$ \\
\hline & Homogenate & $0.49 \pm 0.05$ & $2.42 \pm 0.32 *$ & $0.63 \pm 0.04^{\#, *}$ \\
\hline \multirow{2}{*}{$\begin{array}{l}\text { Arginase, } \\
\mathrm{pmol} / \mathrm{min} / \mathrm{mg} \text { protein }\end{array}$} & $\mathrm{MCH}$ & $2.11 \pm 0.17$ & $8.78 \pm 1.05^{*}$ & $2.23 \pm 0.36^{\#, *}$ \\
\hline & Homogenate & $1.07 \pm 0.1$ & $4.23 \pm 0.31^{*}$ & $0.54 \pm 0.05^{\#, *}$ \\
\hline \multirow{2}{*}{$\begin{array}{l}\mathrm{NO}_{2}^{-}, \\
\mathrm{pmol} / \mathrm{mg} \text { protein }\end{array}$} & $\mathrm{MCH}$ & $488.2 \pm 60.3$ & $159.33 \pm 30.68^{*}$ & $655.6 \pm 97.13^{\#}$ \\
\hline & Homogenate & $354.4 \pm 22.6$ & $214.88 \pm 30.6$ & $825.57 \pm 68.61^{\#, *}$ \\
\hline \multirow{2}{*}{$\begin{array}{l}\mathrm{NO}_{3}^{-}, \\
\mathrm{nmol} / \mathrm{mg} \text { protein }\end{array}$} & $\mathrm{MCH}$ & $76.3 \pm 4.1$ & $83.41 \pm 11.72$ & $17.8 \pm 1.09^{\#, *}$ \\
\hline & Homogenate & $11.72 \pm 0.64$ & $75.45 \pm 8.28 *$ & $16.78 \pm 2.9^{\#}$ \\
\hline \multirow{2}{*}{$\begin{array}{l}\text { LMWNT, } \\
\mathrm{pmol} / \mathrm{mg} \text { protein }\end{array}$} & $\mathrm{MCH}$ & $735.24 \pm 84.9$ & $375.66 \pm 26.03 *$ & $1305.51 \pm 144.17^{\#, *}$ \\
\hline & Homogenate & $178.52 \pm 16.36$ & $67.84 \pm 7.12 *$ & $128.12 \pm 9.46^{\#, *}$ \\
\hline \multirow{2}{*}{$\begin{array}{l}\text { cNOS coupling index, } \\
\text { standart units }\end{array}$} & $\mathrm{MCH}$ & $0.8 \pm 0.08$ & $0.1 \pm 0.02 *$ & $4.85 \pm 0.99^{\#, *}$ \\
\hline & Homogenate & $1.94 \pm 0.43$ & $0.26 \pm 0.05^{*}$ & $4.94 \pm 0.34^{\#, *}$ \\
\hline \multirow{2}{*}{$\begin{array}{l}\mathrm{H}_{2} \mathrm{~S}, \\
\mathrm{nmol} / \mathrm{mg} \text { protein }\end{array}$} & $\mathrm{MCH}$ & $4.58 \pm 0.3$ & $2.38 \pm 0.45^{*}$ & $9.69 \pm 1.53^{\#, *}$ \\
\hline & Homogenate & $22.97 \pm 2.13$ & $12.1 \pm 1.47 *$ & $39.49 \pm 2.05^{\#}$ \\
\hline
\end{tabular}

* $\mathrm{P}<0.05$ relative to adult animals $(100 \%)$. \# $\mathrm{P}<0.05$ relative to old rats, which were not treated with NaHS.

are reduced 3.1 and 1.6 times; arginase activity increases 4.2 and 4 times, and cNOS coupling index is reduced 8 and 7.5 times (see Fig. 3, 4). Thus, during oxidative stress, not only constitutive de novo synthesis of NO is reduced, but also cNOS uncoupling develops, leading to enhanced $\mathrm{O}_{2}{ }^{\bullet}$ production, and hence deepening of oxidative stress.

Apart from the well-known role of nitric oxide as a physiological regulator in the cardiovascular system, excessive simultaneous NO- and oxidant production may cause nitrosative stress. At present, some ways of excessive NO production have been identified: through increased iNOS activity, due to salvage of $\mathrm{NO}$ metabolites $\left(\mathrm{NO}_{3}{ }^{-}\right.$and $\left.\mathrm{NO}_{2}{ }^{-}\right)$by relevant reductases, or decomposition of low- molecular weight nitrosothiols (LMWN). In our studies, iNOS activity increased 2.4 and 8.9 times, the total reductase activity increased 3.2 and 4.9 times, but the levels of LMWNs were reduced 2 and 2.6 times (see Fig. 3). Excess $\mathrm{NO}$ when interacting with ${ }^{\circ} \mathrm{O}_{2}{ }^{-}$promotes generation of a toxic compound, $\mathrm{ONOO}^{-}$, possessing the wide range of damaging actions - from LPO, inactivation of enzymes and ion channels to inhibition of mitochondrial respiration. Peroxynitrite decomposes to form $\mathrm{NO}_{3}{ }^{-}[36,37]$. The pools of the latter in the heart homogenate of old animals exceeded the control value 6.4 times.

Thus, oxidative stress in old animals results in cNOS uncoupling, a decrease in constitutive $\mathrm{NO}$ synthesis, enhanced generation of $\mathrm{O}_{2}{ }^{\bullet-}$ and 

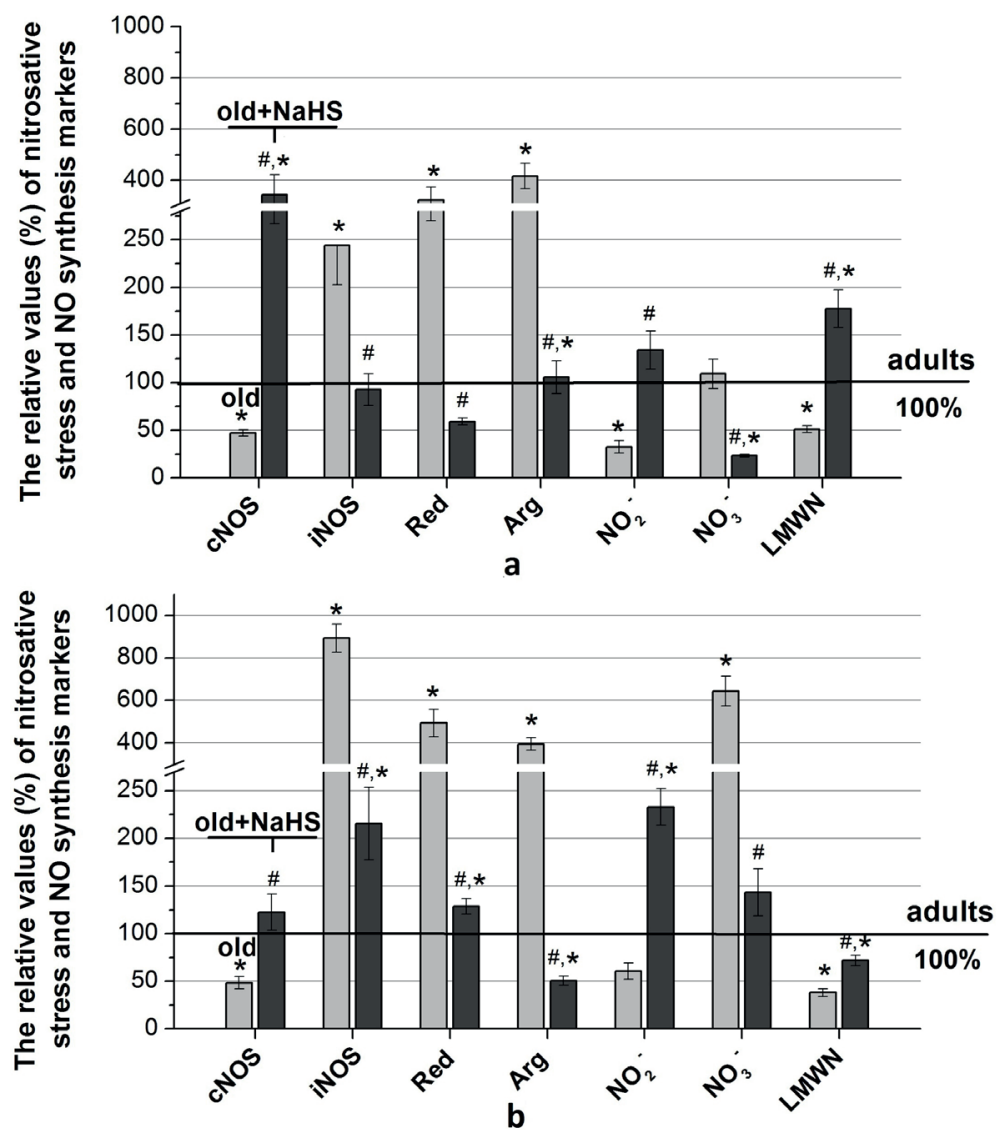

Fig. 3. The relative values of nitrosative stress and constitutive synthesis of NO markers in the mitochondria (a) and homogenate (b) of the heart from old rats before and after NaHS injection: activity of cNOS, activity of iNOS, nitratereductase activity (Red), arginase activity (Arg), $\mathrm{NO}_{2}{ }^{-}$content, content of $\mathrm{NO}_{3}{ }^{-}$, the content of low-molecular-weight nitrosothiols (LMWN). ${ }^{*} \mathrm{P}<0.05$ relative to adult animals $(100 \%)$. \# $\mathrm{P}<0.05$ relative to old rats, which were not treated with NaHS

its highly toxic derivative $\mathrm{ONOO}^{-}$, which results in diastolic dysfunction.
A decrease in endogenous $\mathrm{H}_{2} \mathrm{~S}$ pools 1.9 times (see Fig. 4) in both the mitochondria
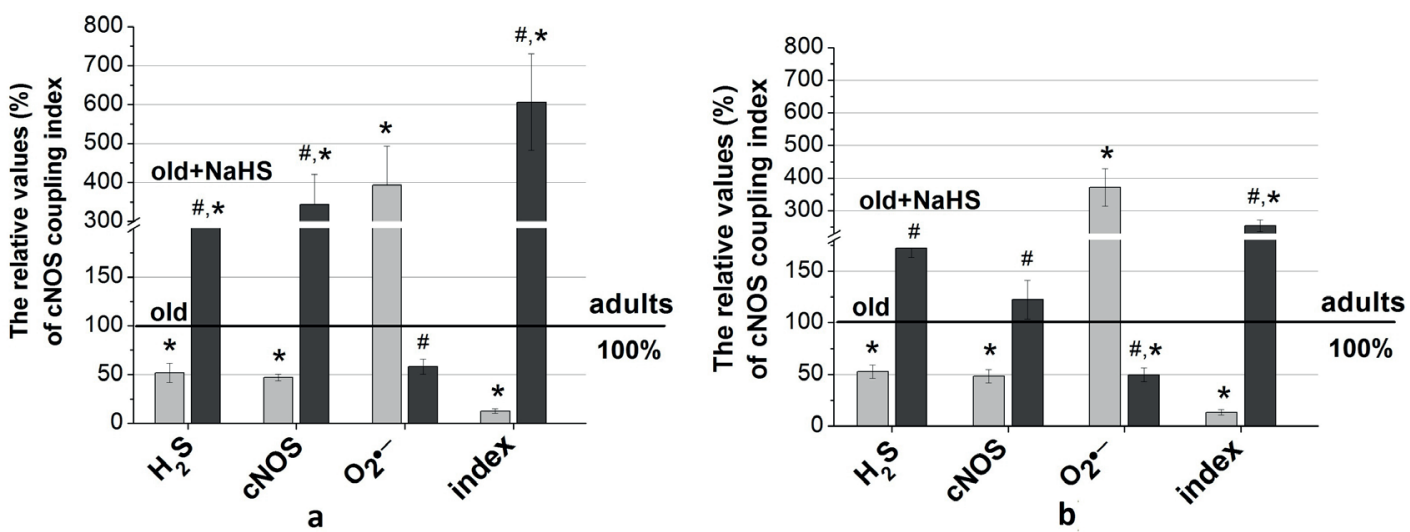

Fig. 4. The relative values of constitutive NO-synthase coupling index and related indices in the mitochondria (a) and homogenate (b) of the heart from old rats before and after NaHS injection: $\mathrm{H}_{2} \mathrm{~S}$ pools, cNOS activity, the rate of $\mathrm{O}_{2} \bullet^{-}$generation, cNOS coupling index (index). ${ }^{*} \mathrm{P}<0.05$ relative to adult animals $(100 \%)$. \# $\mathrm{P}<0.05$ relative to old rats, which were not treated with NaHS 
and homogenate of the heart from old rats should be separately noted, as the latter serves as a regulator of NO synthesis and powerful cardio- and vasoprotector [7-10]. The injection of exogenic hydrogen sulfide donor, NaHS, significantly increased the amount of $\mathrm{H}_{2} \mathrm{~S}$ both in the mitochondria and homogenate of the heart from old animals, which was accompanied by a significant inhibition of both oxidative and nitrosative stress. Oxidative stress (see Fig. 2) was diminished due to the inhibition of all the studied ways of $\mathrm{O}_{2}{ }^{\bullet-}$ generation, and nitrosative stress (see Fig. 3) was inhibited by reducing the excessive generation of $\mathrm{NO}$ and its highly toxic derivative peroxynitrite. At the same time, the recovery of cNOS coupling (see Fig. 4) and increased constitutive de novo synthesis of NO were observed. Restoration of redox status quickly led to an improvement in diastolic function of the heart in old animals.

\section{CONCLUSIONS}

1. In the heart of old rats, we observed both oxidative and nitrosative stress, cNOS uncoupling and reduced constitutive de novo synthesis of nitric oxide. These changes are accompanied by a decrease of $\mathrm{H}_{2} \mathrm{~S}$ pools.

2. The diastolic function of the heart in old rats was impaired (decreased rate of relaxation, increased time constant of left ventricular relaxation, enddiastolic pressure and end-diastolic stiffness).

3. Sodium hydrosulfide (NaHS) suppresses oxidative and nitrosative stress, restores NO coupling and enhances constitutive de novo synthesis of nitric oxide.

4. Administration of NaHS improves left ventricular relaxation in old rats.

\section{К.О. Драчук, Н.О. Дорофєєва, В.Ф. Сагач \\ РОЛЬ СІРКОВОДНЮ У ВІДНОВЛЕННІ ДІАСТОЛІЧНОЇ ФУНКЦІї СЕРЦЯ ПІД ЧАС СТАРІННЯ}

Вивчали вплив донора сірководню $\mathrm{NaHS}$ на вільнорадикальний стан серця, на стан спряження конститутивних
NO-синтаз (cNOS) та показники діастолічної функції серця у старих щурів. Встановили розвиток оксидативного i нітрозативного стресу в мітохондріях і гомогенаті серця. Наслідком цього $є$ неспряження (uncoupling) стану cNOS і зниження конститутивного синтезу NO. В результаті, у старих щурів порушувалася діастолічна функція серця (зменшення на 33\% максимальної швидкості зниження тиску $\left(\mathrm{dp} / \mathrm{dt}_{\min }\right)$, збільшення в 1,5 раза константи активного розслаблення (Tau g), кінцево-діастолічного тиску (в 3 рази) та кінцево-діастолічної жорсткості (в 2 рази)). Встановлено, що NaHS суттєво пригнічував оксидативний і нітрозативний стрес, відновлював спряжений стан cNOS та збільшував конститутивний синтез NO. Це покращувало діастолічну функцію серця у старих щурів внаслідок зростання $\mathrm{dp} / \mathrm{dt}_{\min }$ i зменшення Tau g.

Ключові слова: старіння; серце; оксидативний стре; нітрозативний стрес; неспряження cNOS; сірководень.

\section{К.О. Драчук, Н.А. Дорофеева, В.Ф. Сагач \\ РОЛЬ СЕРОВОДОРОДА В ВОССТАНОВЛЕ- НИИ ДИАСТОЛИЧЕСКОЙ ФУНКЦИИ СЕРДЦА ПРИ СТАРЕНИИ}

Изучали влияние донора сероводорода NaHS на свободнорадикальное состояние сердца, сопряжение конститутивных NO-синтаз (cNOS) и показатели диастолической функции сердца. Установлено развитие оксидативного и нитрозативного стресса в митохондриях и гомогенате сердца старых крыс. Следствием этого есть несопряжение (uncoupling) cNOS и снижение конститутивного синтеза NO. B Результате, у старих крыс развивалась диастолическая дисфункция (снижение на $33 \%$ максимальной скорости падения давления $\left(\mathrm{dp}_{\mathrm{d}} \mathrm{dt}_{\mathrm{min}}\right)$, увеличение в 1,5 раза константы активного расслабления (Tau g) конечно-диастолического давления (в 3 раза) и конечно-диастолической жесткости (в 2 раза)). Введение NaHS существенно угнетало оксидативный и нитрозативный стресс, восстанавливало сопряжение cNOS и увеличивало конститутивній синтез NO. Это способствовало улучшению диастолической функции в результате увеличения на $20 \% \mathrm{dp} / \mathrm{dt}_{\min }$ и уменьшения на 13\% Tau g.

Ключевые слова: старение; сердце; оксидативный стресс; нитрозативный стресс; несопряжение NO; сероводород.

\section{REFERENCES}

1. Hollingsworth KG, Blamire AM, Keavney BD, Macgowan GA. Left ventricular torsion, energetics, and diastolic function in normal human aging. Am J Physiol Heart Circ Physiol. 2012; 302:885-92.

2. Schmidt U, Zhu X, Lebeche D, Huq F, Guerrero JL, Hajjar RJ. In vivo gene transfer of parvalbumin improves diastolic function in aged rat hearts. Cardiovasc Res. 2005; 66:318-23.

3. Zhang Y, Tocchetti CG, Krieg T, Moens AL. Oxidative 
and nitrosattive stress in the maintenance of myocardial function. Free Radic Biol Med. 2012; 53(8):1531-40.

4. Ungvari Z, Gupte SA, Recchia FA, Batkai S, Pacher P. Role of oxidative-nitrosative stress and downstream pathways in various forms of cardiomyopathy and heart failure. Curr Vasc Pharmacol. 2005; 3(3):221-9.

5. Dorofeyeva NA, Kotsjuruba AV, Sagach VF. NOS uncoupling evokes oxidative stress and the cardiohemodynamic disorders in hypertension. Int J Physiol Pathophysiol. 2016; 7(1):71-79.

6. Roe ND, He EY, Wu Z, Ren J. Folic acid reverses nitric oxide synthase uncoupling and prevents cardiac dysfunction in insulin resistance: role of $\mathrm{Ca} 2+/$ calmodulin-activated protein kinase II. Free Radic Biol Med. 2013; 65:234-43.

7. Kondo K, Bhushan S, King AL, Prabhu SD, Hamid T, Koenig S, et al. H2S Protects Against Pressure Overload Induced Heart Failure via Upregulation of Endothelial Nitric Oxide Synthase (eNOS). Circulation. 2013; 127(10):1116-27.

8. King AL, Polhemus DJ, Bhushan S, Otsuka H, Kondo K, Nicholson CK, et al. Hydrogen sulfide cytoprotective signaling is endothelial nitric oxide synthase-nitric oxide dependent. Proc Natl Acad Sci. 2014;111(8):3182-7.

9. Shen Y, Zhen Z, Luo S, Guo W, Zhu YZ. The cardioprotective effects of hydrogen sulfide in heart diseases: from molecular mechanisms to therapeutic potential. Oxid Med Cell Longev. 2015; 2015 [Electronic resource]. Access mode https://www.hindawi.com/journals/ omcl/2015/925167/

10. Polhemus DJ, Lefer DJ. Emergence of hydrogen sulfide as an endogenous gaseous signaling molecule in cardiovascular disease. Circ Res. 2014;114(4):730-7.

11. Pacher P, Nagayama T, Mukhopadhyay P, Batkai S, Kass DA. Measurement of cardiac function using pressurevolume conductance catheter technique in mice and rats. Nat Protoc. 2008; 9:1422-34.

12. Drachuk KO, Kotsjuruba AV, Sagach VF. Hydrogen sulfide donor, NaHS, recovers constitutive NO synthesis and endothelium-dependent relaxation of isolated aorta in old rats. Fiziol Zh. 2015; 61(6):3-10. [Ukrainian].

13. McCord JM, Roy RS. The pathophysiology of superoxide: roles in inflammation and ischemia. Can J Physiol Pharmacol. 1982; 60(11):1346-52.

14. Halliwell B, Grootveld M, Gutteridge J. Methods for the measurement of hydroxyl radicals in biomedical systems: deoxyribose degradation and aromatic hydroxylation. MethodsBiochem Anal. 1988; 33:59-90.

15. Huwiler M, Kohler H. Pseudo-catalytic degradation of hydrogen peroxide in the lactoperoxidase/H2O2/iodide system.Eur J Biochem.1984; 141(1):69-74.

16. Sharipov RR, Kotsjuruba AV, Kop»iak BS, Sagach VF. Induction of oxidative stress in heart mitochondria under focal cerebral ischemia-reperfusion and protective effect of ecdysterone. Int J Phys Pathophysiol. 2015; 6(2):157-64.

17. Jialal I, Devaraj S. Low-density lipoprotein oxidation, antioxidants and atherosclerosis: a clinical biochemistry perspective. Clin Chem. 1996; 42:498-506.

18. Mihara M, Uchiyama M. Determination malonaldehyde precursor in tissues by thiobarbituric acid test. Anal Biochem. 1978; 86(1):271-8.

19. Salter M, Knowles RG, Moncada S. Widespread tissue distribution, species and changes in activity of $\mathrm{Ca}^{2+}$ -dependent and $\mathrm{Ca}^{2+}$-independent nitric oxide syntases. FEBS Lett. 1991; 291(1):145-149.

20. Chin SY, Pandey KN, Shi SJ, Kobori H, Moreno C, Navar LG. Increased activity and expression of $\mathrm{Ca}^{2+}$-dependent NOS in renal cortex of ANG II-infused hypertensive rats. Amer J Physiol. 1999; 277(5):797-804.

21. Bryan NS, Grisham MB. Methods to detect nitric oxide and its metabolites in

22. biological samples. Free Radic Biol Med. 2007; 43(5):645-57.

23. Green LL, WagnerDA, GlogowskiJ, SkipperPL, Wishnok JS, TannenbaumSR.Analysis of nitrate, nitrite and $[+5 \mathrm{~N}]$ nitrate in biological fluids. Anal Biochem. 1982; 126(1):131-8.

24. Svenson A. A rapid and sensitive spectrophotometric method for determination of hydrogen sulfide with 2,2'-dipyridyl disulfide. Anal. Biochem. 1980; 107:51-5.

25. Sagach VF, Vavilova GL, Strutyns'ka NA, Rudyk OV. The aging increase in the sensitivity of the mitochondrial permeability transition pore opening to inductors in rat heart. Fiziol Zh. 2004; 50(2): 49-63 [Ukrainian].

26. Lowry OH, Rosebrough NJ, Farr AL, Randall RJ. Protein measurement with the Folin phenol reagent. J Biol Chem. 1951; 193(1):265-75.

27. Asp ML, Martindale JJ, Heinis FI, Wang W, Metzger JM. Calcium mishandling in diastolic dysfunction: mechanisms and potential therapies. Biochim Biophys Acta. 2013; 1833(4):895-900.

28. Gouspillou G, Bourdel-Marchasson I, Rouland R, Calmettes G, Biran M, Deschodt-Arsac V, et al. Mitochondrial energetics is impaired in vivo in aged skeletal muscle. Aging Cell. 2014;13(1):39-48.

29. Sullivan-Gunn MJ, Lewandowski PA. Elevated hydrogen peroxide and decreased catalase and glutathione peroxidase protection are associated with aging sarcopenia. BMC Geriatr. 2013; 13:104.

30. Griguer CE, Oliva CR, Kelley EE, Giles GI, Lancaster JR Jr, Gillespie GY. Xanthine oxidase-dependent regulation of hypoxia-inducible factor in cancer cells. Cancer Res. 2006; 66(4):2257-63.

31. Kayyali US, Donaldson C, Huang H, Abdelnour R, Hassoun PM. Phosphorylation of xanthine dehydrogenase/oxidase in hypoxia. J Biol Chem. 2001; 276(17):14359-65.

32. Shelat PB, Chalimoniuk M, Wang JH, Strosznajder JB, Lee JC, Sun AY, etal. Amyloid beta peptide and NMDA induce ROS from NADPH oxidase and AA release from cytosolic phospholipase A2 in cortical neurons. J Neurochem. 2008; 106(1):45-55.

33. Brown WJ, Chambers K, Doody A. Phospholipase A2 (PLA2) enzymes in membrane trafficking: mediators 
of membrane shape and function. Traffic. 2003; 4(4):214-21.

34. Sun GY, Xu J, Jensen MD, Simonyi A. Phospholipase A2 in the central nervous system: implications for neurodegenerative diseases. J Lipid Res. 2004; 45(2): 205-13.

35. Jensen FB. The role of nitrite in nitric oxide homeostasis: a comparative perspective. Biochim Biophys Acta. 2009; 1787(7):841-8.

36. El Assar M, Angulo J, Vallejo S, Peiry C, S6nchez-Ferrer
CF, Rodrhguez-Macas L. Mechanisms involved in the aging-induced vascular dysfunction. Front Physiol. 2012; [Electronic resource]. Access mode http://journal. frontiersin.org/article/10.3389/fphys.2012.00132/full

37. Beckman JS, Koppenol WH. Nitric oxide, superoxide, and peroxynitrite: the good, the bad, and ugly. Am J Physiol. 1996; 271(5):1424-37.

38. Szaby C. The pathophysiological role of peroxynitrite in shock, inflammation, and ischemia-reperfusion injury. Shock. 1996; 6(2):79-88. 